\title{
KONTRIBUSI KEPEMIMPINAN, MOTIVASI KERJA, IKLIM KERJA, DAN KEPUASAN KERJA TERHADAP KINERJA PEGAWAI DI FAKULTAS BAHASA DAN SENI UNIVERSITAS PENDIDIKAN GANESHA
}

\author{
Gede Widiartana, I Made Yudana, Sudirman \\ Program Studi Administrasi Pendidikan, Program Pascasarjana \\ Universitas Pendidikan Ganesha \\ Singaraja, Indonesia
}

e-mail: \{gede.widiartana, made.yudana, sudirman\}@pasca.undiksha.ac.id.

\begin{abstract}
Abstrak
Penelitian ini bertujuan untuk mengetahui Kontribusi Kepemimpinan, Motivasi Kerja, Iklim Kerja, dan Kepuasan Kerja Terhadap Kinerja Pegawai di Fakultas Bahasa dan Seni Universitas Pendidikan Ganesha. Penelitian ini adalah penelitian "ex-post facto" dengan besar sampel 38 orang. Data dikumpulkan dengan kuesioner dan dokumen. Analisis data dilakukan dengan teknik regresi sederhana, regresi ganda, dan korelasi parsial. Hasil penelitian menunjukkan bahwa: (1) terdapat kontribusi yang signifikan antara kepemimpinan dengan kinerja pegawai di Fakultas Bahasa dan Seni Undiksha dengan koefisien korelasi sebesar 0,593 , kontribusi sebesar $35,2 \%$ dan sumbangan efektifnya sebesar $12,48 \%$. (2) terdapat kontribusi yang signifikan antara motivasi kerja dengan kinerja pegawai di Fakultas Bahasa dan Seni Undiksha, dengan koefisien korelasi sebesar 0,833, kontribusi sebesar $69,4 \%$ dan sumbangan efektifnya sebesar $42,51 \%$. (3) terdapat kontribusi yang signifikan antara iklim kerja dengan kinerja pegawai di Fakultas Bahasa dan Seni Undiksha dengan koefisien korelasi sebesar 0,684, kontribusi sebesar $46,8 \%$ dan sumbangan efektifnya sebesar $13,51 \%$.( 4) terdapat kontribusi yang signifikan antara kepuasan kerja dengan kinerja pegawai di Fakultas Bahasa dan Seni Undiksha dengan koefisien korelasi sebesar 0,769, kontribusi sebesar $59,2 \%$ dan sumbangan efektifnya sebesar $17,31 \%$. 5) secara bersama-sama, terdapat kontribusi yang signifikan antara kepemimpinan, motivasi kerja, iklim kerja, dan kepuasan kerja terhadap kinerja pegawai di Fakultas Bahasa dan Seni Undiksha dengan koefisien korelasi ganda sebesar 0,926 dan kontribusinya sebesar 85,8\% terhadap kinerja pegawai di Fakultas Bahasa dan Seni Undiksha.
\end{abstract}

Kata kunci: kepemimpinan, motivasi kerja, iklim kerja, kepuasan kerja, kinerja pegawai

\begin{abstract}
This study aims to determine the contribution of leadership, work motivation, work atmosphere, and job satisfaction on employees' performance in Faculty of Language and Arts, Ganesha University of Education. This study is an ex-post facto study with the number of samples as many as 38 people. The data were collected with questionnaires and documents. Data analysis was performed by simple regression, multiple regression, and partial correlation. The results showed that: (1) there was a significant contribution between leadership and employee performance in Faculty of Language and Arts Undiksha with correlation coefficient was 0,593 , contribution of $35,2 \%$ and effective contribution equal was $12,48 \%$. (2) There was a significant contribution between work motivation and employees' performance in Language and Arts Faculty Undiksha with correlation coefficient of 0,833 , contribution of $69,4 \%$ and effective contribution of $42.51 \%$. (3) There was significant contribution between work atmosphere and employees' performance in Faculty of Language and Arts Undiksha with correlation coefficient was 0,684 , contribution of $46,8 \%$ and effective contribution was $13,51 \%$. (4) There was significant contribution between job satisfaction and employees' performance in Language and Arts Faculty Undiksha with correlation coefficient was 0,769 , contribution of $59,2 \%$ and effective contribution was $17,31 \%$. (5) Simultaneously, there was a significant contribution between leadership, work motivation, work atmosphere, and job satisfaction on employees' performance in Faculty of Language and Arts with double correlation coefficient was 0,926 and its contribution was $85,8 \%$ to employee performance in Faculty of Language and Arts, Undiksha.
\end{abstract}

Keywords: leadership, work motivation, work climate, job satisfaction, employee performance 


\section{PENDAHULUAN}

Kinerja pegawai berkaitan dengan kualitas dan kuantitas suatu pekerjaan yang dilakukan pegawai atau bawahan serta yang berkaitan dengan kondisi suatu bawahan atau pegawai padaorganisasi tertentu. Kinerja yang baik adalah kinerja yang optimal, yaitu kinerja yang sesuai standar organisasi dan mendukung tercapainya tujuan organisasi.

Organisasi pasti menginginkan para pegawainya memiliki kinerja yang baik agar proses pencapaian tujuan berjalan dengan lancar. Dalam mewujudkan kinerja pegawai yang diinginkan, terdapat banyak faktor yang mempengaruhi pegawai antara lain kepemimpinan pada organisasi tersebut, kompensasi, motivasi, iklim kerja dan lain sebagainya. Berkaitan dengan hal tersebut, dalam penelitian ini akan membahas empat faktor yang diidentifikasi mempengaruhi kinerja pegawai yaitu, kepemimpinan, motivasi kerja, iklim kerja, dan kepuasan kerja.

Kinerja pegawai di perguruan tinggi selalu menjadi pusat perhatian, karena pegawai merupakan salah satu faktor penentu dalam meningkatkan mutu pendidikan dan berperan dalam meningkatkan kualitas pendidikan.

Pegawai seharusnya memiliki potensi yang cukup tinggi untuk berkreasi guna meningkatkan kinerjanya. Namun potensi yang dimiliki pegawai untuk berkreasi sebagai upaya meningkatkan kinerjanya tidak selalu berkembang secara wajar dan lancar disebabkan adanya pengaruh dari berbagai faktor baik yang muncul dalam pribadi pegawai itu sendiri maupun yang terdapat di luar pribadi pegawai.

Seperti yang telah diketahui masyarakat luas, Universitas Pendidikan Ganesha merupakan institusi pendidikan tinggi negeri yang mencetak sumber daya manusia dalam bidang kependidikan dan non kependidikan. Untuk dalam bidang kependidikan, Universitas Pendidikan Ganesha merupakan pencetak sumber daya manusia pendidik yang terbesar di Bali. Untuk mendukung kelancaran dibidang administrasi dan pelayanan terhadap mahasiswa peran pegawai sangat penting sehingga kegiatan administrasi yang ada di Universitas Pendidikan Ganesha dapat berjalan dengan baik.

Dari pengamatan observasi yang telah dilakukan terkait kinerja pegawai yang ada di Fakultas Bahasa dan Seni Universitas Pendidikan Ganesha, pada bagian hubungan masyarakat (humas) misalnya masih sering ditemukan terjadi ketimpangan informasi yang terkait dalam kegiatan di Fakultas Bahasa dan Seni Undiksha, seperti tidak diketahui secara detail tentang informasi yang ada, sehingga yang membutuhakan informasi tidak mendapat apa yang ingin diperoleh. Selain itu juga ditemukan permasalahan pada bagian kemahasiswaan, terutama pada masalah beasiswa, disini sering ditemukan perlakuan kurang adil terhadap penerima bea siswa serta didalam pencairan bea siswa.

Berdasarkan permasalahan yang dipaparkan tersebut diatas menunjukkan masih adanya hal-hal terkait kinerja pegawai Fakultas Bahasa dan Seni Universitas Pendidikan Ganesha yang masih harus dikaji lebih lanjut. Dalam proses mancapai tujuan lembaga diperlukan pengukuran terhadap keberhasilan yang harus dicapai oleh setiap pegawai secara individu. Penilaian kinerja individu sangat bermanfaat bagi perkembangan lembaga secara keseluruhan, melalui penilaian kinerja pegawai tersebut maka dapat diketahui kondisi sebenarnya tentang bagaimana kinerja yang diberikan seorang pegawai pada lembaga tempatnya bekerja.

Faktor yang dapat mempengaruhi kinerja pegawai adalah kepemimpinan. Secara teoretis, semakin tepat gaya kepemimpinan yang diterapkan oleh seorang pemimpin, maka kinerja yang ditunjukkan pegawai akan semakin baik. Hal ini disebabkan karena semakin tepat gaya kepemimpinan seorang pemimpin, maka semangat dan rasa tanggung jawab pegawai terhadap tugas yang menjadi tanggungjawabnya akan semakin tinggi sehingga kinerja yang ditunjukkan juga semakin meningkat. Kenyataan yang terjadi dilapangan, banyak pemimpin yang menerapkan gaya kepemimpinan yang kurang relevan dengan paradigma kepemimpinan saat ini. 
Selanjutnya faktor yang dapat mempengaruhi dan digunakan untuk meningkatkan kinerja pegawai, di antaranya motivasi kerja, Motivasi merupakan daya dorong yang mengakibatkan seseorang bersedia dan rela untuk menggerakkan kemampuan dalam bentuk keahlian atau keterampilan, tenaga dan waktu untuk menyelenggarakan kegiatan tertentu (Siagian, 2004:14). Motivasi merupakan istilah yang mengacu pada faktor-faktor yang ada pada individu untuk membangkitkan atau mempertahankan perilaku dalam mencapai tujuan tertentu. Dengan demikian motivasi berprestasi merupakan seluruh daya penggerak yang berasal dari dalam maupun dari luar diri seseorang yang menimbulkan keinginan untuk berprestasi.

Untuk mewujudkan kinerja pegawai yang berkualitas tidak terlepas dari motivasi kerja yang dimiliki oleh pegawai dalam menjalankan tugas. Motivasi kerja yang dimiliki pegawai secara teoretis berkaitan dengan motivasi kerja pegawai. Pemahaman tentang motivasi mengacu pada pengertian yang dirumuskan oleh Berelson dan Steiner (dalam Wijana, 2009:48), yang menyatakan bahwa motif adalah suatu keadaan dari dalam yang memberi kekuatan, menggiatkan atau menggerakkan, dan mengarahkan atau menyalurkan perilaku seseorang ke arah pencapaian tujuan.

Faktor selanjutnya yang dapat mempengaruhi kinerja pegawai adalah iklim kerja. Menurut Litwin dan Stringer dalam Hoy dan Miskel (2008:198), iklim kerja adalah seperangkat sifat terukur dari lingkungan kerja, berdasarkan persepsi kolektif masyarakat yang tinggal dan bekerja di lingkungan dan terbukti mempengaruhi tingkah laku mereka. Hal ini berarti Iklim kerja sekolah yang kondusif akan berdampak pada kinerja guru. Hal tersebut mencerminkan bahwa suasana sekolah yang kondusif sangat mendukung peningkatan kinerja guru.

Iklim kerja sebagai suatu konsep yang mereflesikan isi dan kekuatan nilai-nilai umum, norman, sikap, tingkah laku, dan perasaan anggota terhadap suatu sistem. Iklim kerja diperguruan tinggi diidentifikasikan sebagai perangkat atribut yang memberi warna atau karakter, spirit, etos, suasana batin, dari setiap perguruantinggi secara operasional, sebagaimana halnya pengertian iklim pada cuaca, iklim kerja di perguruan tinggi diukur dengan menggunakan rata-rata dari persepsi komunitas perguruan tinggi terhadap aspek-aspek yang menentukan lingkungan kerja.

Dari hasil pengamatan yang dilakukan pada Fakultas Bahasa dan Seni Undiksha ada kecendrungan kinerja pegawai dalam melaksanakan tugasnya menurun, hal ini nampak dari beberapa indikasi, seperti : belum maneingkatnya nilai akreditasi dan turunnya jumlah penerimaan mahasiswa baru di beberapa program studi, lambatnya penyelesaian pekerjaan, hubungan kerja diantara sesama pegawai terkadang kurang harmonis, kurang efektifnya dalam melaksanakan pekerjaan. Padahal pihak Fakultas Bahasa dan Seni Undiksha telah melaksanakan kegiatan-kegiatan terkait dengan sumber daya manusianya berupa pelatihan kepegawaian, workshop dan seminar-seminar bahkan mengundang motivator. Yang diharapkan dari pelaksanaan kegiatan-kegiatan tersebut ada hasil feedback diantaranya yaitu terciptanya iklim kerja yang kondusif dan stabil sehingga terwujudnya kinerja yang baik dan maksimal dari pegawai-pegawai pada semua unit kerja di Fakultas Bahasa dan Seni Undiksha untuk menghadapi tantangan dan tuntutan jaman yang yang semakin kompetitif.

Keadaan ini dipengaruhi oleh iklim kerja yang kurang baik, sebagai konsekuensi logis untuk dapat mengatasi permasalahan tersebut diperlukan adanya suatu penataan personil bagi segenap pegawai untuk bisa mendorong terciptanya kinerja yang tinggi melalui peningkatan kinerja pegawai

Terakhir yang faktor yang dapat mempengaruhi kinerja pegawai adalah kepuasan kerja. Kepuasan kerja merupakan sikap umum seorang karyawan terhadap pekerjaannya (Robbins, 1996:182). Kepuasan kerja menunjukkan adanya kesesuaian antara harapan seseorang yang timbul dengan imbalan yang disediakan oleh pekerjaan. Porter (dalam Luthans, 1995:175) menambahkan job satisfaction is difference between how much of something there should be and how much there is now". Maksudnya kepuasan kerja adalah perbedaan antara seberapa banyak sesuatu yang seharusnya diterima dengan seberapa banyak sesuatu yang sebenarnya dia terima). Jadi, berdasarkan beberapa pendapat di atas dapat disimpulkan bahwa: (a) 
kepuasan kerja merupakan suatu tanggapan emosional seseorang terhadap siatuasi dan kondisi kerja (b) tanggapan emosional bisa berupa perasaan puas (positif) atau tidak puas negatif). Bila perasaan emosionalnya puas berarti kepuasan kerja tercapai sebaliknya bila tidak berarti karyawan tidak puas (c) kepuasan kerja dirasakan karyawan setelah karyawan tersebut membandingkan antara apa yang dia harapkan diperoleh dari hasil kerjanya dengan apa yang sebenarnya dia peroleh dari hasil kerjanya (d) kepuasan kerja mencerminkan beberapa sikap yang berhubungan (Luthans, 1995:180).

Dari beberapa teori dan hasil penelitian bahwa kepuasan kerja memiliki pengaruh yang signifikan terhadap kinerja pegawai. Dalam hal ini kepuaan kerja kepuasan kerja menjadi hal penting untuk diteliti. Karena kepuasan kerja adalah merupakan salah satu faktor yang dapat mempengaruhi kinerja pegawai. Dalam bekerja tentunya setiap pegawai ingin merasakan kepuasan dalam bekerja. Baik dalam lingkungan kerja, rekan kerja maupun kepuasan dari segi pekerjaannya. Oleh karena itu, khususnya sebagai seorang pimpinan dalam sebuah lembaga penting untuk memperhatikan kepuasan kerja para pegawainya. Karena pencapaian tujuan organisasi atau lembaga dimulai dari cara pegawainya bekerja. Kemudian, pegawai yang memeiliki kepuasan kerja yang tinggi akan berdampak pula terhadap kinerja pegawai tersebut. Mengingat hal tersebut, kepuasan kerja menjadi salah satu faktor yang penting untuk diperhatikan dalam meningkatkan kinerja pegawai.

Dalam hal ini, Fakultas Bahasa dan Seni Universitas Pendidikan Ganesha perlu mewujudkan peran pelayanan yang optimal sesuai dengan harapan masyarakat pengguna (user) atau para mahasiswa. Pelayanan yang berkualitas dapat menunjukkan adanya kinerja yang optimal, baik kinerja pegawai maupun kinerja organisasinya.

Dari Uraian di atas, maka dari itu tertarik untuk mengetahui lebih jauh melalui penelitian yang difokuskan mengenai kontribusikepemimpinan, motivasi kerja, iklim kerja dan kepuasan kerja terhadap kinerja pegawai di Fakultas Bahasa dan Seni Universitas Pendidikan Ganesha. Berdasarkan uraian yang ditemukan dan sekaligus untuk memfokuskan pembahasan dalam penelitian ini, maka judul tesis yang diambil sebagai berikut: "Kontribusi Kepemimpinan, Motivasi Kerja, Iklim Kerja, dan Kepuasan Kerja Terhadap Kinerja Pegawai diFakultas Bahasa dan seni Universitas Pendidikan Ganesha”.

\section{METODE PENELITIAN}

Penelitian ini menggunakan pendekatan "ex-post facto". Karena dalam penelitian ini tidak diadakan perlakuan (treatment atau manipulasi) terhadap sampel penelitian. Sukardi (2007 :165) menyatakan bahwa penelitian ex-post facto merupakan penelitian dimana variablevariabel bebas telah terjadi ketika peneliti mulai dengan pengamatan variable terikat dalam suatu peneletian. Pada penelitian ini, keterkaitan antar variabel dengan variabel bebas, maupun antar variabel dengan variabel terikat sudah terjadi secara alami, dan peneliti dengan setting tersebut ingin melacak kembali jika dimungkinkan apa yang menjadi faktor penyebabnya.

Kerlinger (2002:240) juga berpendapat ex-post facto merupakan penyelidikan empiris yang sistemmatis, dimana ilmuan tidak mengendalikan varibel bebas secara langsung karena perwujudan variabel tersebut telah terjadi, atau karena variabel tersebut pada dasarnya tidak dimanipulasi.Berdasarkan pemaparan para ahli diatas maka dapat disimpulkan bahwa penelitian ex-post facto merupakan penelitian empiris yang sistemmatis dengan keterkaitan antar variabelnya sudah terjadi secara alami tanpa campur tangan peneliti.

Menurut Sugiono (2008:117) populasi adalah wilayah generalisasi yang terdiri atas objek/subjek yang mempunyai kualitas dan karakteristik tertentu yang ditetapkan oleh peneliti untuk dipelajari dan kemudian ditarik kesimpulannya. Populasi dalam penelitian ini adalah seluruh pegawai di Fakultas Bahasa dan Seni. Jumlah seluruh pegawai di Fakultas Bahasa dan Seni adalah sebanyak 38 orang.

Sampel penelitian adalah sebagian dari populasi yang diambil, yang diaangap mewakili seluruh populasi dan diambil menggunakan teknik tertentu (Agung, 2014:45), sedangkan 
menurut Sukardi (2003:54) sampel adalah sebagian dari jumlah populasi yang dipilih untuk sumber data.Hal senada juga dinyatakan oleh Sugiono (2008: 118) yang menyatakan bahwa sampel adalah bagian dari jumlah dan karakteristik yang dimiliki oleh populasi.Jadi dapat disimpulkan bahwa sampel adalah bagian dari seluruh populasi yang dijadikan objek penelitian.

Dalam penelitian ini teknik penentuan sampel yang digunakan adalah sampling jenuh atau sensus.Pengertian dari sampling jenuh atau sensus menurut Sugiyono (2008:122) adalah: Sampling jenuh atau sensus adalah teknik penentuan sampel bila semua anggota populasi digunakan sebagai sampel.

Berdasarkan dari pengertian tersebut, maka dapat diketahui bahwa sampling jenuh atau sensus teknik penentuan sampel dengan menggunakan semua anggota populasi. Dikarenakan populasi penelitian ini tidak terlalu banyak, maka seluruh populasi digunakan sebagai sampel penelitian dalam penelitian ini yakni berjumlah 38 orang pegawai.

Variabel bebas dalam penelitian ini adalah kepemimpinan(X1), motivasi kerja (X2), iklim kerja (X3) dan kepuasan kerja (X4). Adapun variabel terikatnya adalah kinerja pegawai (Y).hubungan antara varibel bebasa dan variabel terikat secara sederhana dapat digambarkan konstelasi permasalahan.

Alat pengumpul data harus memenuhi persyaratan yaitu syarat validitas dan reliabilitas dalam mengungkap apa yang hendak diukur. Ada dua persyaratan yang hendak digunakan dalam pengumpulan data penelitian yaitu validitas dan reliabilitas (Hamzah, $2001: 63$ ). Validitas instrumen dalam penelitian ini meliputi dua segi yaitu validitas isi dan validitas butir. Validitas isi dibantu oleh dua orang ahli/ expert, kemudian dianalisis dengan teknik Gregory.

Sebelum instrumen digunakan, maka perlu diuji dahulu validitas dari masing-masing pertanyaan yang ada sebagai alat pengambilan data. Dengan demikian terlebih dahulu diadakan uji coba terhadap kuisioner kemudian hasil uji coba ini dianalisis. Untuk menguji validitas butir rumus yang digunakan adalah rumus kontribusi product moment dari Pearson (Arikunto, 1995).

Pengujian terhadap reabilitas instrumen dilakukan melalui pendekatan ketetapan internal. Uji reliabilitas adalah ketepatan dan keajegan alat pengukur tersebut dalam menilai apa yang diinginkan, artinya kapanpun alat tersebut digunakan akan diperoleh hasil yang sama (Puger, 2004). Pengujian reliabilitas dengan rumus Alpha dari Crombach (Arikunto, 1997:164).

Kegiatan analisis data terdiri atas kegiatan pengolahan data dan analisis statistik. Kegiatan analisis data meliputi: 1) menyunting data secara manual. Penyuntingan dilakukan karena kemungkinan ada data yang tidak jelas, atau kesalahan dalam pengisian instrument, sehingga tidak memenuhi syarat untuk dianalisis, 2) mentabulasi data, dan 3) mengolah data dalam bentuk sesuai kebutuhan.

Untuk menguji hipotesis yang telah dirumuskan, terlebih dahulu dilakukan analisis data yang telah dikumpulkan. Dalam melakukan analisis data untuk penelitian ini dilakukan dengan tiga tahapan yakni: 1) tahap deskripsi data, 2) tahap pengujian persyarat analisis, 3) tahap pengujian hipotesis.

Data yang telah diperoleh dari penelitian dideskripsikan menurut masing-masing variable. Oleh tujuannya seperti itu, maka akan dicari harga rerata (M), standar deviasi (SD), modus (Mo), dan median (Me) setiap variabel yang diteliti.

Setelah data dideskripsikan, maka analisis dilanjutkan dengan menggunakan teknik regresi sederhana, regresi ganda, dan korelasi varsial. Persyaratan yang berkaitan dengan teknik analisis data tersebut harus dibuktikan secara statistik.

Setelah seluruh uji prasyarat terpenuhi, maka dilanjutkan dengan uji hipotesis. Untuk menguji hipotesis pertama, kedua, ketiga dan keempat dalam penelitian ini digunakan teknik analisis korelasi sederhana (korelasi product moment pearson). Sedangkan untuk menguji hipotesis ke empat, digunakan teknik analisis korelasi ganda, regresi ganda, dan korelasi parsial. Untuk menganalisis uji hipotesis dalam penelitian ini digunakan program SPSS-17.00 for windows. 


\section{HASIL PENELITIAN DAN PEMBAHASAN}

\section{Kontribusi Kepemimpianan terhadap Kinerja Pegawai Fakultas Bahasa dan Seni Undiksha}

Berdasarkan analisis data yang telah dilakukan, secara normatif ditemukan bahwa kepemimpinan berada pada kategori sangat baik. Selain itu, hasil analisis juga menunjukkan bahwa terdapat korelasi yang signifikan antara kepemimpinan dengan kinerja pegawai di Fakultas Bahasa dan Seni Undiksha melalui persamaan garis regresi $\hat{y}=33,231+$ 0,739.X1dengan Freg $=19,523(p<0,05)$. Sedangkan korelasi yang signifikan terjadi antara kepemimpinan dengan kinerja pegawai sebesar 0,593 dengan $p<0,05$ dan variabel kepemimpinan dapat menjelaskan kinerja pegawai di Fakultas Bahasa dan Seni Undiksha sebesar $35,2 \%$. Temuan ini mengindikasikan bahwa kepemimpinan mempunyai peranan penting dalam meningkatkan kinerja pegawai di Fakultas Bahasa dan Seni Undiksha. Sumbangan efektif (SE) variabel kepemimpinan terhadap kinerja pegawai di Fakultas Bahasa dan Seni Undiksha adalah sebesar $12,48 \%$.

Temuan dalam penelitian ini sejalan dengan temuan penelitian yang dilakukan oleh $\mathrm{G}$. Bernadetha Nadeak (2017) berjudul The Effect Of The Cultural Organization, Leadership, Job Satisfaction, and Organizational Citizenship Behavior Lecturer In The Christian University Of Indonesia menerangkan bahwa perbaikan dan peningkatan kepemimpinan kaprodi sebagai pemimpin yang kuat dapat menyebabkan meningkatnya kepuasan kerja dosen.

Kepemimpinan merupakan kemampuan untuk menggerakkan, mempengaruhi, memotivasi, mengajak, mengarahkan, menasehati, membimbing, menyuruh, memerintah, melarang, dan bahkan menghukum bila diperlukan, serta membina dengan maksud agar anggota organisasi sebagai media manajemen mau bekerja dalam rangka mencapai tujuan administrasi secara efektif dan efisien. Kepemimpinan sangat menentukan berhasil atau gagalnya seorang pemimpin dalam mengelola organisasi atau institusi tertentu.

Gaya kepemimpinan merupakan suatu pola perilaku seorang pemimpin yang khas pada saat mempengaruhi bawahannya. Semakin efektif gaya kepemimpinan yang diterapkan seorang pemimpin dalam mengelola suatu lembaga, maka pegawai sebagai bawahan akan merasa tergerakkan, terpengaruhi, termotivasi, terarahkan, dan terbimbing dalam menjalankan tugas. Berdasarkan pemaparan di atas dapat dikatakan bahwa terdapat kontribusi yang positif dan signifikan antara gaya kepemimpinan yang diterapkan pemimpin dengan kinerja pegawai di Fakultas Bahasa dan Seni Undiksha.

\section{Kontribusi Motivasi terhadap Kinerja Pegawai Fakultas Bahasa dan Seni Undiksha}

Berdasarkan analisis data yang telah dilakukan, secara normatif ditemukan bahwa motivasi kerja berada pada kategori sangat baik. Selain itu, hasil analisis juga menunjukkan bahwa terdapat korelasi yang signifikan antara motivasi kerja dengan Di Fakultas Bahasa dan Seni Undiksha melalui persamaan garis regresi $\hat{y}=89,018+1,538 X 2$ dengan Freg $=81,485$ $(p<0,05)$. Sedangkan korelasi yang signifikan terjadi antara motivasi kerja dengan kinerja pegawai sebesar 0,833 dengan $\mathrm{p}<0,05$ dan variabel motivasi kerja dapat menjelaskan Di Fakultas Bahasa dan Seni Undiksha sebesar 69,4\%. Temuan ini mengindikasikan bahwa motivasi kerja mempunyai peranan penting dalam meningkatkan kinerja pegawai di Fakultas Bahasa dan Seni Undiksha. Sumbangan efektif (SE) variabel motivasi kerja terhadap kinerja pegawai di Fakultas Bahasa dan Seni Undiksha adalah sebesar 42,51\%.

Temuan dalam penelitian ini sejalan dengan temuan penelitian yang dilakukan oleh Deikme (2013) yang berjudul Motivasi Kerja dan Budaya Organisasi Pengaruhnya terhadap Kinerja Pegawai bagian Keuangan Sekda Kabupaten Mimika Provinsi Papua, Kesimpulan hasil penelitian dan analisis: 1). Motivasi kerja dan budaya organisasi secara bersama berpengaruh positif dan signifikan terhadap kinerja pegawai 2). Motivasi kerja berpengaruh secara positif dan signifikan terhadap kinerja pegawai 3 ). Budaya organisasi berpengaruh secara positif dan signifikan terhadap kinerja pegawai. 
Motivasi merupakan kekuatan yang ada dalam diri seseorang dalam memberi daya, memberi arah atau memelihara tingkah laku. Motivasi merupakan suatu proses psikologis yang mencerminkan intraksi antara sikap, kebutuhan, persepsi dan keputusan yang terjadi dalam diri seseorang. Pegawai yang memiliki motivasi tinggi dalam proses pelaksanaan pekerjaan senantiasa mengikuti proses pekerjaan dengan semangat bekerja yang tinggi. Motivasi dinyatakan sebagai sesuatu yang membuat orang bertindak atau berbuat untuk mencapai tujuan yang telah ditentukan sebelumnya. Secara sederhana dikatakan bahwa motivasi adalah proses pemberian motif (penggerak) atau penggerak andanya perilaku yang ditujukan kepada pencapaian kepuasan kebutuhan, sehingga tujuan yang telah dirumuskan bisa tercapai.

Motivasi kerja didefinisikan sebagai semua upaya yang dilakukan untuk memunculkan semangat dari dalam diri maupun dari luar diri seseorang agar bersedia menjalankan pekerjaan yang menjadi tugasnya. Dilihat dari segi motivasi kerja, pada diri seorang pegawai terdapat kekuatan mental yang menjadi penggerak untuk bekerja. Kekuatan penggerak tersebut berasal dari berbagai sumber yang dapat meningkatkan motivasi. Pada awalnya motivasi kerja yang tergolong rendah berubah menjadi lebih baik setelah pegawai memperoleh informasi yang benar. Demikian pula halnya motivasi kerja yang tergolong rendah dapat dirubah menjadi motivasi kerja yang tinggi. Hal ini bisa terjadi apabila pemimpin sebagai atasan memiliki kemampuan untuk meningkatkan motivasi kerja pegawai.

Meningkatnya motivasi kerja pegawai dalam mengelola proses pekerjaan yang ada di fakultas akan berdampak positif terhadap kualitas pelaksanaan penyelesaian tugas yang ada di fakultas. Semakin tinggi motivasi kerja maka pelaksanaan proses penyelesaian pekerjaanakan semakin baik. Sebaliknya, semakin rendah motivasi kerja pegawai maka pelaksanaan proses penyelesaian pekerjaan akan semakin kurang baik. Dengan demikian dapat dikatakan bahwa terdapat kontribusi secara signifikan antara motivasikerja pegawai dengan kinerja pegawai di Fakultas Bahasa dan Seni Universitas Pendidikan Ganesha.

\section{Kontribusi Iklim Kerja terhadap Kinerja Pegawai Fakultas Bahasa dan Seni Undiksha}

Berdasarkan analisis data yang telah dilakukan, secara normatif ditemukan bahwa iklim kerja berada pada kategori sangat baik. Selain itu, hasil analisis juga menunjukkan bahwa terdapat korelasi yang signifikan antara iklim kerja dengan kinerja pegawai di Fakultas Bahasa dan Seni Undiksha melalui persamaan garis regresi $\hat{y}=6,107+0,890 X 3$ dengan Freg $=31,631$ $(p<0,05)$. Sedangkan korelasi yang signifikan terjadi antara iklim kerja dengan kinerja pegawai sebesar 0,684 dengan $p<0,05$ dan variabel iklim kerja dapat menjelaskan kinerja pegawai di Fakultas Bahasa dan Seni Undiksha sebesar 46,8\%. Temuan ini mengindikasikan bahwa iklim kerja mempunyai peranan penting dalam meningkatkan kinerja pegawai di Fakultas Bahasa dan Seni Undiksha. Sumbangan efektif (SE) variabel iklim kerja terhadap kinerja pegawai di Fakultas Bahasa dan Seni Undiksha adalah sebesar 13,51\%.

Hasil penelitian ini sejalan dengan hasil penelitian yang dilakukan oleh Subhan (2017) yang berjudul Analisis Pengawasan dan Iklim Organisasi terhadap Kepuasan Kerja dan Disiplin Kerja pada Polres Semarang menerangkan bahwa penelitian ini menunjukan pengawasan berpengaruh signifikan positif terhadap kepuasan kerja, semakin baik pengawasan yang dilakukan maka semakin tinggi kepuasan kerja. Iklim organisasi berpengaruh signifikan positif terhadap kepuasan kerja, semakin baik iklim organisasi maka semakin tinggi kepuasan kerja. Kepuasan kerja berpengaruh signifikan positif terhadap disiplin kerja, semakin tinggi kepuasan kerja maka semakin baik disiplin kerja. Pengawasan berpengaruh signifikan positif terhadap disiplin kerja, bahwa semakin baik pengawasan maka semakin baik disiplin kerja. Iklim organisasi berpengaruh signifikan positif terhadap disiplin kerja, semakin baik iklim organisasi maka semakin baik disiplin kerja.

Iklim kerja merupakan suatu kondisi atau keadaan susasana kerja lembaga dirasa nyaman, tenang dan bebas dalam melakukan pekerjaan tanpa ada rasa terpaksa maupun tidak nyaman, dan berganti menjadi keadaan yang harmonis, keadaan yang harmonis akan tercipta apabila hubungan masing-masing individu dapat memposisikan dirinya sebagai anggota dari 
sebuah lembaga yang harus saling bekerjasama dalam pelaksanaan tugasnya, hal ini akan dapat menciptakan iklim kerja yang kondusif ditengah perbedaan yang ada pada masingmasing pegawai.

Jadi dapat disimpulan jika iklim kerja di Fakultas Bahasa dan Seni dalam melaksanakan pekerjaannya pegawai merasa nyaman, tenang, harmonis dan kondusif maka iklim kerja di fakultas tersebut dikatakan baik, sebaliknya apabila iklim kerja kurang nyaman, tenang, harmonis, serta hubungan masing-masing individu tidak dapat memposisikan dirinya sebagai anggota dari lembaga tersebut dan tidak saling bekerjasama dalam pelaksanaan tugasnya, hal ini akan dapat menciptakan iklim kerja yang kurang kondusif ditengah perbedaan yang ada pada masing-masing pegawai. Dengan demikian dapat dikatakan bahwa terdapat kontribusi signifikan antara iklim kerja dengan kinerja pegawai di Fakultas Bahasa dan Seni Universitas Pendidikan Ganesha.

\section{Kontribusi Kepuasan Kerja terhadap Kinerja Pegawai Fakultas Bahasa dan Seni Undiksha}

Berdasarkan analisis data yang telah dilakukan, secara normatif ditemukan bahwa kepuasan kerja berada pada kategori baik. Selain itu, hasil analisis juga menunjukkan bahwa terdapat korelasi yang signifikan antara kepuasan kerja dengan kinerja pegawai di Fakultas Bahasa dan Seni Undiksha melalui persamaan garis regresi $\hat{y}=83,905+1,662 X 4$ dengan Freg $=52,159(p<0,05)$. Sedangkan korelasi yang signifikan terjadi antara kepuasan kerja dengan kinerja pegawai sebesar 0,769 dengan $p<0,05$ dan variabel kepuasan kerja dapat menjelaskan kinerja pegawai di Fakultas Bahasa dan Seni Undiksha sebesar 59,2\%. Temuan ini mengindikasikan bahwa kepuasan kerja mempunyai peranan penting dalam meningkatkan kinerja pegawai di Fakultas Bahasa dan Seni Undiksha. Sumbangan efektif (SE) variabel kepuasan kerja terhadap kinerja pegawai di Fakultas Bahasa dan Seni Undiksha adalah sebesar $17,31 \%$.

Hasil penelitian ini sejalan dengan hasil penelitian yang dilakukan oleh Arnanta dan Mudiartha (2017) berjudul Pengaruh Stres Kerja, Kepuasan Kerja dan Iklim Organisasi terhadap Turnover Intention Karyawan CV. Simpulan yang diperoleh dalam penelitian ini stres kerja berpengaruh positif terhadap turnover intention yang ditunjukkan dari nilai $\beta=0,323$ dan $s i g=0,00$. Kepuasan kerja berpengaruh negatif dan signifikan terhadap turnover intention. Hal tersebut ditunjukkan dari nilai $\beta=-0,318$ dan $s i g=0,00$. Kontribusi kepuasan kerja untuk menjelaskan turnover intention sebesar $-0,164$ dan Iklim organisasi berpengaruh negatif dan signifikan terhadap turnover intention yang ditunjukkan dari nilai $\beta=-0,744$ dan sig $=0,00$ Kontribusi iklim organisasi untuk menjelaskan turnover intention sebesar -0,357.

Kepuasan kerja pegawai merupakan masalah yang penting, karena ada bukti yang kuat kepuasan kerja memberi manfaat yang besar bagi kepentingan individu, instansi, dan masyarakat. Kepuasan kerja pegawai sering menyangkut tentang emosi atau kondisi perasaan terhadap suatu pekerjaan.Kepuasan sebenarnya merupakan keadaan yang sifatnya subyektif yang merupakan hasil didasarkan pada suatu perbandingan mengenai apa yang diterima pegawai dari pekerjaannya dibandingkan dengan yang diharapkan, diinginkan, dan dipikirkannya sebagai hal yang pantas atau berhak atasnya. Sementara setiap karyawan/ pegawai secara subyektif menentukan bagaimana pekerjaan itu memuaskan.

Jadi Pegawai yang mempunyai kepuasan kerja yang tinggi akan dapat melakukan tugas dengan baik dan penuh semangat. Dengan demikian dapat katakan bahwa terdapat kontribusi signifikan antara kepuasan kerja dengan kinerja pegawai di Fakultas Bahasa dan Seni Universitas Pendidikan Ganesha.

\section{Kontribusi Kepemimpinan, Motivasi Kerja, Iklim Kerja, dan Kepuasan Kerja terhadap Kinerja Pegawai Fakultas Bahasa dan Seni Undiksha}

Berdasarkan analisis yang telah dilakukan, ditemukan bahwa terdapat korelasi yang signifikan secara bersama-sama antara kepemimpinan kepala sekolah, motivasi kerja, iklim 
kerja, dan kepuasan kerja terhadap kinerja pegawai melalui persamaan garis regresi $\hat{y}=$ $147,670+0,262 X 1+0,942 X 2+0,257 X 3+0,486 X 4$ dengan Freg $=49,692(p<0,05)$. Ini berarti terdapat hubungan secara bersama-sama antara kepemimpinan, motivasi kerja, iklim kerja, dan kepuasan kerja terhadap kinerja pegawai di Fakultas Bahasa dan Seni Undiksha. Hal ini mengindikasikan bahwa makin baik kepemimpinan, motivasi kerja, iklim kerja, dan kepuasan kerja makin baik pula kinerja pegawai tersebut.

Korelasi murni antara kepemimpinan, motivasi kerja, iklim kerja, dan kepuasan kerja dengan kinerja pegawai di Fakultas Bahasa dan Seni Undiksha yang diperoleh melalui analisis korelasi parsial jenjang kedua. Hasil yang diperoleh adalah: pertama, terdapat korelasi yang signifikan antara variabel kepemimpinan terhadap kinerja pegawai dengan dikendalikan oleh variabel motivasi kerja, iklim kerja, dan kepuasan kerja $\left(r_{1 y-234}=0,593\right)$ dengan $\left.p<0,05\right)$. Ini menunjukkan bahwa kepemimpinan memberikan kontribusi yang signifikan terhadap kinerja pegawai di Fakultas Bahasa dan Seni Undiksha, sehingga dapat dijadikan prediktor kecenderungan tingkat kinerja pegawai di Fakultas Bahasa dan Seni Undiksha.

Kedua, terdapat korelasi yang signifikan motivasi kerja terhadap kinerja pegawai dengan dikendalikan oleh variabel kepemimpinan, iklim kerja, dan kepuasan kerja $\left(r_{2 y-134}=0,833\right.$ dengan $p>0,05)$. Ini menunjukkan bahwa motivasi kerja memberikan kontribusi terhadap kinerja pegawai di Fakultas Bahasa dan Seni Undiksha, sehingga dapat dijadikan prediktor kecenderungan tingkat kinerja pegawai di Fakultas Bahasa dan Seni Undiksha.

Ketiga, terdapat korelasi yang signifikan antara iklim kerja terhadap kinerja pegawai dengan dikendalikan oleh variabel kepemimpinan, motivasi kerja, dan kepuasan kerja $\quad\left(r_{3 y-124}=\right.$ $0,684$ dengan $p>0,05)$. Ini menunjukkan bahwa iklim kerja memberikan kontribusi terhadap kinerja pegawai di Fakultas Bahasa dan Seni Undiksha, sehingga dapat dijadikan prediktor kecenderungan tingkat kinerja pegawai di Fakultas Bahasa dan Seni Undiksha.

Keempat, terdapat korelasi yang signifikan antara kepuasan kerja terhadap kinerja pegawai dengan dikendalikan oleh variabel kepemimpinan, motivasi kerja dan iklim kerja ( $r_{4 y}$ $123=0,769$ dengan $p>0,05$ ). Ini menunjukkan bahwa kepuasan kerja memberikan kontribusi terhadap kinerja pegawai di Fakultas Bahasa dan Seni Undiksha, sehingga dapat dijadikan prediktor kecenderungan tingkat kinerja pegawai di Fakultas Bahasa dan Seni Undiksha.

Kekuatan hubungan keempat variabel bebas dengan kinerja pegawai di Fakultas Bahasa dan Seni Undiksha secara berurutan adalah: kepemimpinan, motivasi kerja, iklim kerja, dan kepuasan kerja mempunyai kontribusi terhadap kinerja pegawai.

\section{PENUTUP}

Berdasarkan hasil penelitian dan pembahasan yang telah dilakukan, maka dapat ditarik kesimpulan sebagai berikut.

Pertama, ada kontribusi yang signifikan antara kepemimpinan terhadap kinerja pegawai di Fakultas Bahasa dan Seni Undiksha dengan koefisien korelasi sebesar 0,593 dan sumbangan efektifnya sebesar $12,48 \%$.

Kedua, ada kontribusi yang signifikan antara motivasi kerja terhadap kinerja pegawai di Fakultas Bahasa dan Seni Undiksha. dengan koefisien korelasi sebesar 0,833 dan sumbangan efektifnya sebesar $42,51 \%$.

Ketiga, ada kontribusi yang signifikan antara iklim kerja terhadap kinerja pegawai di Fakultas Bahasa dan Seni Undiksha dengan koefisien korelasi sebesar 0,684 dan sumbangan efektifnya sebesar $13,51 \%$.

Keempat, ada kontribusi yang signifikan antara kepuasan kerja terhadap kinerja pegawai di Fakultas Bahasa dan Seni Undiksha dengan koefisien korelasi sebesar 0,769 dan sumbangan efektifnya sebesar $17,31 \%$.

Kelima, secara bersama-sama, ada kontribusi yang signifikan antara kepemimpinan, motivasi kerja, iklim kerja, dan kepuasan kerja terhadap kinerja pegawai di Fakultas Bahasa dan Seni Undiksha dengan koefisien korelasi ganda sebesar 0,926 dan kontribusinya sebesar 85,8\% terhadap kinerja pegawai di Fakultas Bahasa dan Seni Undiksha. 
Berdasarkan hasil dan kesimpulan dari penelitian ini, dapat diajukan beberapa saran sebagai berikut.

Pegawai hendaknya mampu untuk meningkatkan motivasi kerja yang dimiliki, terbentuknya motivasi kerja yang baik akan menciptakan semangat dan kegairahan pegawai untuk berprestasi dalam menjalankan tugas yang diharapkan akan bermuara pada peningkatan kualitas dalam proses pelaksanaan tugas di dalam suatu lembaga.

Pimpinan hendaknya mampu untuk meningkatkan kepemimpinannya, semakin tepat gaya kepemimpinan yang diterapkan oleh seorang pemimpin, maka kinerja yang ditunjukkan pegawai akan semakin baik. Hal ini disebabkan karena semakin tepat gaya kepemimpinan seorang pemimpin, maka semangat dan rasa tanggung jawab pegawai terhadap tugas yang menjadi tanggungjawabnya akan semakin tinggi sehingga kinerja yang ditunjukkan juga semakin meningkat.

Peneliti lain diharapkan mampu mengembangkan variabel lain dalam usaha meningkatkan kinerja pegawai.

\section{DAFTAR RUJUKAN}

Agung, Anak Agung Gede. 2014. Metodologi Penelitian Pendidikan. Malang: Aditya Media Publishing.

Arikunto, Suharsimi. 1995. Manajemen Penelitian. Jakarta: Rineka Cipta.

Arikunto, Suharsimi. 1997. Prosedur Penelitian Suatu Pendekatan Praktek. Jakarta: Rineka Cipta.

Deikme, Pilatus. 2013. Motivasi Kerja dan Budaya Organisasi Pengaruhnya terhadap Kinerja Pegawai bagian Keuangan Sekda Kabupaten Mimika Provinsi Papua. Jurnal Emba. Vol.1 No.3 Juni 2013, Hal.980-986

Hamzah, B. Uno. 2001. Teori Motivasi dan Pengukurannya. Jakarta: Bumi Aksana.

Hoy, Wayne K \& Cecil G Miskel. 2008. Educational Administration: Theory, Research, and Practice. Singapure: Mc Graw-Hill Co.

Kerlinger, Fred N. 2004. Asas-asas Penelitian Behavioral. Edisi Ketiga. Diterjemahkan oleh Landung R. Simatupang. 1986. Foundation of Behavioral Research. Third Edition. Yogyakarta: Gadjah Mada University Press.

Kerlinger. 2002. Korelasi dan Analisis Regresi Ganda. Yogyakarta : Nur Cahya

Luthans, Fred. 1995. Organizational Behavior. Mc.Graw Hill International, New York.

Mudiartha. 2017. Pengaruh Stres Kerja, Kepuasan Kerja dan Iklim Organisasi terhadap Turnover Intention Karyawan CV. Dharma Siadja. e-Jurnal Manajemen Unud, Vol. 6, No. 6, 2017: 3314-3341.

Nadeak, G. Bernadetha. 2016. The Effect Of The Cultural Organization, Leadership, Job Satisfaction, and Organizational Citizenship Behavior Lecturer In The Christian University Of Indonesia. Jurnal IImiah Educational Management. Vol.7, No.1.

Puger, I Gusti Ngurah. 2004. Belajar Kooperatif. Diktat Perkuliahan Mahasiswa Unipas 
Robbins, Stephen P. 1996. Perilaku Organisasi, Konsep, Kontroversi dan Aplikasi. Alih Bahasa: Hadyana Pujaatmaka. Edisi Keenam. Jakarta: PT.Bhuana Ilmu Populer.

Siagian, Sondang P. 2004. Manajemen Sumber Daya Manusia. Jakarta: Bumi. Aksara

Subhan. 2017. Analisis Pengawasan dan Iklim Organisasi terhadap Kepuasan Kerja dan Disiplin Kerja pada Polres Semarang. Seminar Nasional dan Call for Paper 2017. Strategi Pengembangan Sumber Daya Manusia Melalui Publikasi Jurnal IImiah dalam Menyikapi Permenristekdikti RI No.20 Tahun 2017.

Sugiyono, 2008. Metode Penelitian Kunatitatif Kualitatif dan $R \& D$. Bandung Alfabeta

Sukardi. 2003. Metodologi Penelitian Pendidikan Kompetensi dan Prakteknya. Jakarta: Bumi Aksara

Sukardi. 2007. Metodologi Penelitian Pendidikan. Jakarta: PT.Bumi Aksara

Wijana dan Muhammad Rohmadi. 2009. Analisis Wacana Pragmatik Kajian Teori dan Analisis. Surakarta: Yuma Pustaka 